\title{
Development of Evaluation Methods for Lower Limb Function between Aged and Young Using Principal Component Analysis
}

\author{
Yohei Nomoto Non-member (University of Niigata Prefecture, nomoto@unii.ac.jp) \\ Kazuhiko Yamashita Member (Tokyo Healthcare University) \\ Tetsuya Ohya Nom-member (Tokyo Denki University) \\ Hironori Koyama Non-member (Tokyo Denki University) \\ Masashi Kawasumi Non-member (Tokyo Denki University)
}

Keywords : Aged, Young, Lower limb function, Evaluation methods

Falling is one of the most common and serious problems because advancing age has been associated with muscle weakness, reduced walking ability and deterioration of postural control system. Falling causes the hip fracture and the bed-bound, and increases national medical expenses for the aged. About $1 \%$ of falls cause hip fracture and $5 \%$ result in any type of fracture. Decade from now with the graying of the baby-boom generation, it is indicated that fall-related problems such as hip fractures will quadruple over the next 40 years. It is easy to assume that the fall-related problems will heavily task the health care systems, as the medical expenses for the aged, unless effective approaches to prevent falls and develop new method and device about prevention falls. The some of falling factors are reported the decrease of the muscular strength of the lower-limb, postural control and walking ability. However the methods and device which evaluated quantitatively lower limb function are not developed. The aim of this study was to develop multiple evaluation methods in order to advise for improvement and maintenance of lower limb function between aged and young.

The subjects were 16 healthy young volunteers (mean \pm S.D: $19.9 \pm 0.6$ years) and 10 healthy aged volunteers (mean \pm S.D: $80.6 \pm 6.1$ years). Measurement items related to lower limb function were selected from the items which we have ever used. Selected measurement items of function of lower are distance of extroversion of the toe, angle of flexion of the toe, maximum width of step, knee elevation, moving distance of greater trochanter, walking balance, toe-gap force and rotation range of ankle joint.

Table1 shows the result of the selected measurement items of function of lower the relationship between the young healthy participants and elderly healthy participants.

As the result, the young healthy participants demonstrated the factor of 1.9 greater distance of extroversion of the toe compared with the elderly healthy participants. The young healthy participants demonstrated the factor of 1.6 greater angle of flexion of the toe compared with the elderly healthy participants. The young healthy participants demonstrated the factor of 1.3 greater maximum width of step compared with the elderly healthy participants. The young healthy participants demonstrated the factor of 3.1 greater knee elevation compared with the elderly healthy participants. The decrease because of the aging of the
Table 1. Average and standard deviation of measurement items

\begin{tabular}{lcc}
\hline \multicolumn{1}{c}{ Measurment items [unit] } & $\begin{array}{c}\text { Aged } \\
\text { Average } \pm \text { SD } \\
\mathrm{n}=10\end{array}$ & $\begin{array}{c}\text { Young } \\
\text { Average } \pm \mathrm{SD} \\
\mathrm{n}=16\end{array}$ \\
\hline Distance of extroversion of the toe [cm] & $1.5 \pm 0.7$ & $2.9 \pm 1.0 * *$ \\
Angle of flexion of the toe [deg] & $28.0 \pm 7.1$ & $46.3 \pm 16.6 * *$ \\
Maximum width of step & $1.1 \pm 0.2$ & $1.5 \pm 0.3 * *$ \\
Knee elevation & $0.12 \pm 0.02$ & $0.39 \pm 0.11^{* *}$ \\
Moving distance of greater trochanter & $0.14 \pm 0.01$ & $0.09 \pm 0.02 * *$ \\
Waling balance & $1.8 \pm 0.1$ & $2.0 \pm 0.2 * *$ \\
Toe-gap force [N] & $2.5 \pm 1.2$ & $3.5 \pm 1.1$ \\
Rotation range of ankle joint [deg] & $37.2 \pm 8.7$ & $44.9 \pm 8.4 * *$ \\
\hline$* * \mathrm{p}<.01$ & &
\end{tabular}

moving distance of greater trochanter was confirmed. The decrease because of the walking balance was confirmed. The young healthy participants demonstrated the factor of 1.3 greater distance of extroversion of the toe compared with the elderly healthy participants. The young healthy participants demonstrated the factor of 1.2 greater rotation range of ankle joint compared with the elderly healthy participants.

Measurement items summarized by the principal component analysis into lower ability evaluation methods including walking ability and muscle strength of lower limb and flexibility of ankle.

The average value and standard deviation of the assessment score of walking ability are shown as follows. The young healthy participants demonstrated the factor of 1.6 greater the assessment score of walking ability compared with the aged group.

The average value and standard deviation of the assessment score of muscle strength of lower limb for all subjects are shown as follows. The young healthy participants demonstrated the factor of 1.4 greater the assessment score of muscle strength of lower limb compared with the aged group.

The average value and standard deviation of the assessment score of flexibility of ankle for all subjects are shown as follows. The young healthy participants demonstrated the factor of 1.2 greater the assessment score of flexibility of ankle compared with the aged group.

The results suggested that it was possible to assess the lower limb function of aged and young numerically and to advise on their foot function. 


\title{
主成分分析を用いた高齢者と若年者の下肢機能の評価手法の開発
}

\author{
非会員 野本 洋平* \\ 正 員 山下 和彦** \\ 非会員 大矢 哲也*** 非会員 小山 裕徳*** \\ 非会員 川澄 正史***
}

\section{Development of Evaluation Methods for Lower Limb Function between Aged and Young Using Principal Component Analysis}

Yohei Nomoto*, Non-member, Kazuhiko Yamashita**, Member, Tetsuya Ohya***, Non-member, Hironori Koyama***, Non-member, Masashi Kawasumi***, Non-member

There is the increasing concern of the society to prevent the fall of the aged. The improvement in aged people's the muscular strength of the lower-limb, postural control and walking ability are important for quality of life and fall prevention. The aim of this study was to develop multiple evaluation methods in order to advise for improvement and maintenance of lower limb function between aged and young. The subjects were 16 healthy young volunteers (mean \pm S.D: $19.9 \pm 0.6$ years) and 10 healthy aged volunteers (mean \pm S.D: $80.6 \pm 6.1$ years). Measurement items related to lower limb function were selected from the items which we have ever used. Selected measurement items of function of lower are distance of extroversion of the toe, angle of flexion of the toe, maximum width of step, knee elevation, moving distance of greater trochanter, walking balance, toe-gap force and rotation range of ankle joint. Measurement items summarized by the principal component analysis into lower ability evaluation methods including walking ability and muscle strength of lower limb and flexibility of ankle. The young group demonstrated the factor of 1.6 greater the assessment score of walking ability compared with the aged group. The young group demonstrated the factor of 1.4 greater the assessment score of muscle strength of lower limb compared with the aged group. The young group demonstrated the factor of 1.2 greater the assessment score of flexibility of ankle compared with the aged group. The results suggested that it was possible to assess the lower limb function of aged and young numerically and to advise on their foot function.

キーワード : 高齢者, 若年者, 下肢機能, 評価手法

Keywords : Aged, Young, Lower limb function, Evaluation methods

\section{1. はじめに}

高齢者の転倒は社会的問題であり ${ }^{(1)}$, 高齢者医療費, 介護

* 新潟県立大学 国際地域学部 国際地域学科

干950-8680 新潟県新潟市東区海老ヶ瀬 471

University of Niigata Prefecture, Faculty of International Studies and Regional Development, Department of International Studies and Regional Development

471, Ebikase, Higashi-ku, Niigata 950-8680

** 東京医療保健大学 医療保健学部 医療情報学科

干154-8568 東京都世田谷区世田谷 3-11-3

Tokyo Healthcare University, Faculty of Health Care, Division of Healthcare Informatics

3-11-3, Setagaya Setagaya-ku, Tokyo 154-8568

*** 東京電機大学 未来科学部情報メディア学科

厂101-8457 東京都千代田区神田錦町 2-2

Tokyo Denki University, School of Science and Technoligy For Future Life, Department of Information Systems and Multimedia Design

2-2, Kanda Nishikicho, Chiyoda-ku, Tokyo 101-8457
費用の高騰を引き起こすだけでなく, いちじるしく日常生 活動作 (Activity of Daily Living:ADL) の低下を引き起こす ため, 日本各地の地方自治体や高齢者施設で転倒予防のた めの運動指導プログラムなどが実施されている。

転倒の予防には下肢筋力や姿勢制御能, および歩行能力 の維持・向上が求められ(2) (4), 定量的評価に基づいた転倒 リスクを推定することが重要である。

効果的な転倒予防を行うためには, 事前のアセスメント, 対象者に合わせた介入プログラムの作成, および事後の効 果判定が不可欠である。特に転倒予防教室において, 対象 者の身体機能を計測することは, アセスメントのような評 価基準としての適用に加え, 対象者本人の運動や生活への 意欲を高めることがこれまでにわかっており，今後さらに 普及するものと思われる。

我々は高齢者の下肢筋力, 姿勢制御能, 歩行能力を簡便 
かつ客観的に評価する計測機器や評価手法の開発について 研究を進めてきた (5) (7)。さらに地方自治体や転倒予防のた めの運動指導の現場で利用することを想定し，これまでに 研究してきた下肢筋力, 歩行能力などの計測結果から新た な評価手法（以下，下肢機能評価手法とする。）の構築と介 入による下肢機能評価手法の利用面の検討を行ってきた ${ }^{(8)}$ 。 しかし, 本研究で提案した下肢機能評価手法は, 特別養護 老人ホームに住む高齢者 10 名のみを対象として作成したた め，利用者が限定される。そこで本論文では，身体機能が 高いと考えられる若年者を加え, 高齢者や若年者といった 幅広く評価ができる下肢機能評価手法の作成を行った。

\section{2. 下肢機能評価手法}

〈2·1〉 下肢機能評価手法作成の手順 下肢機能評価 手法の作成では，下肢筋力や歩行能力などの項目を実際に 計測し, 得られたデータから高齢者と若年者における下肢 機能評価手法の検討を行った。また, 本実験の計測項目は, これまでに我々が用いた計測項目 12 項目から ${ }^{(5) \sim(7)}$, 高水準 の身体機能を必要とする項目, 複雑な機器を必要とする項 目, 専門的知識が必要となる項目, 合計 7 項目を除き代替 として最大一歩幅, 足指外転距離, 足指屈曲角度の 3 項目 を加えた, 計 8 項目を選定した。下肢機能評価手法の提示 では高齢者や若年者, および運動実施者の理解を補助する ために, 主成分分析によって歩行能力, 下肢筋力, 足首柔 軟性の 3 つのパラメータに要約することとした。

\section{$\langle 2 \cdot 2\rangle \quad$ 歩行能力に関する計測項目}

$\langle 2 \cdot 2 \cdot 1\rangle$ 足指外転距離足指柔軟性（以下，足指外 転距離とする。）が制限されることは，適切な筋力の発揮が 阻害され, 筋力の低下につながる原因となる ${ }^{(9)}$ 。筋機能の構 造変化は, 筋力発揮が正常になされない可能性があるとと もに，足指外転距離の著しい制限につながると考える。ま た，足指運動機能は動的バランスとの相関が高いと報告さ れている(10)。そこで我々は, 適切な筋力発揮や動的バラン スと相関の高い足指外転距離に着目し，歩行能力に含める こととした。

足指外転距離の計測は，椅座位で行えるため安全である。 対象者の姿勢は膝関節を 90 度とし，踵を上げないように注 意した。計測回数は左右足 2 回ずつ行い, 2 回のうち大きい 方の計測值を記録した。図 1 に足指外転距離の計測風景を 示す。計測はノギスを用い，足母指と第二指の最大に開い た距離 $\ell_{1}$ を計測した。計測精度は $0.05 \mathrm{~mm}$, 最大值が $150 \mathrm{~mm}$ である。

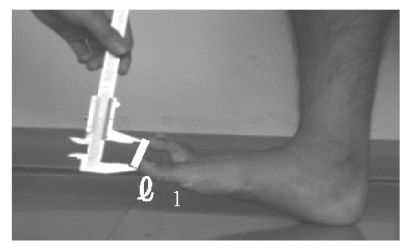

図 1 足指外転距離

Fig. 1. Measurement of distance of extroversion of the toe $\langle 2 \cdot 2 \cdot 2\rangle$ 足指屈曲角度 立脚相後期の蹴りだしの力 は, 前脛骨筋, 下腿三頭筋, 足底筋が重要である。また, 足母指の異常は立脚相後期の蹴りだしの最終的な力の発揮 経路であり, 動作範囲（以下，足指屈曲角度とする）が制 限されていると，筋力が正常に発揮されない可能性がある とともに足母指の動作範囲の制限につながる(5)。そこで本研 究では, 歩行に関する蹴りだしの力の発揮に関わる足指屈 曲角度に着目することとした。

足指屈曲角度の計測は, 椅座位で行えるため安全である。 対象者の姿勢は, 膝関節を 90 度とし, 踵を上げないように 注意した。計測回数は左右足 2 回ずつ行い, 2 回のうち大き い方の計測值を記録した。図 2 の足指屈曲角度の計測では, $\mathrm{A}$ の第 1 基節骨と $\mathrm{B}$ の内果に万能角度計を当て $\theta_{1}$ の角度を 計測した ${ }^{(11)}$ 。万能角度計は 1 度きざみに 180 度まで計測で きる。

$\langle 2 \cdot 2 \cdot 3\rangle$ 最大一歩幅高齢者は加齢により股関節の 柔軟性が低下し, 股関節の関節可動域が減少する。さらに 片足を踏み出し, 最大一歩幅の姿勢を維持することは, そ の状態を保持する下肢の静的な筋力であるアイソメトリッ ク収縮を必要とする ${ }^{(11)}$ 。

計測方法は，立位で両足を揃えた状態から計測する足を ゆっくりずらすように前方に踏み出し, 最大距離を保持さ せその距離を計測した。その際，手で足を支持することを 禁止した。最大一歩幅の計測は左右 2 回ずつとし， 2 回のう ち大きい方の計測值を記録した。最大一歩幅の計測值は, 各対象者の下肢長で除し，正規化した。

$\langle 2 \cdot 2 \cdot 4\rangle$ 膝関節の上昇值 歩行中の遊脚期の膝関節 の上昇值の低下は, 転倒誘発要因の一つである。すなわち 歩行周期の立脚相後期の踣りだしの力の低下は, 遊脚期の 膝関節位置の低下を引き起こし，つまづきを誘発する。そ こで本研究では, 歩行中の蹴りだしの力と膝関節の上昇值 は関係があると考え, 膝関節の上昇值に着目し歩行能力の 計測項目に採用した。

膝関節の上昇值の計測では, 動作解析のためのマーカ位 置を図 3 の B.膝関節外顆に取り付け ${ }^{(11)}$, デジタルビデオカ メラの撮影画像（連続静止画）より, 歩行中の膝関節の上 昇值 $\mathrm{B}_{\delta}$ を 2 歩行周期における最大值から抽出し, 時系列デ 一タの垂直軸における最大值 $\mathrm{B}_{\mathrm{y} 2}$, 基準值 $\mathrm{B}_{\mathrm{y} 1}$ を各対象者の 静止立位時として (1)式より求めた。膝関節の上昇值は, 各 対象者の下肢長で除し, 正規化した。下肢長は, 対象者の 上前腸骨棘から外果までの距離とする。

$\langle 2 \cdot 2 \cdot 5\rangle$ 大転子の変動量 人間の歩行中の身体重心

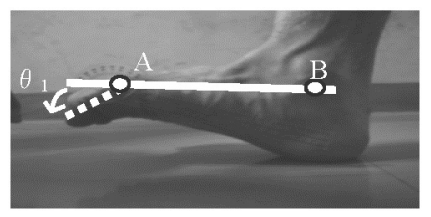

図 2 足指屈曲角度

Fig. 2. Angle of flexion of the toe 


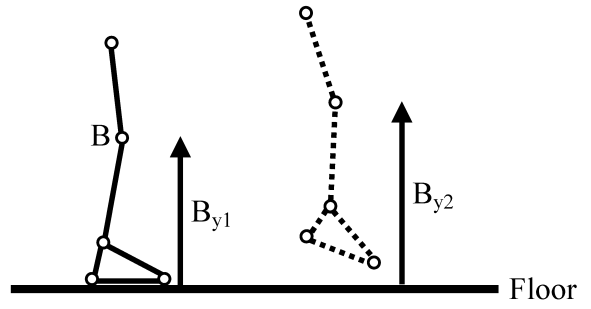

図 3 膝関節の上昇值の計測位置

Fig. 3. Measurement of the knee elevation

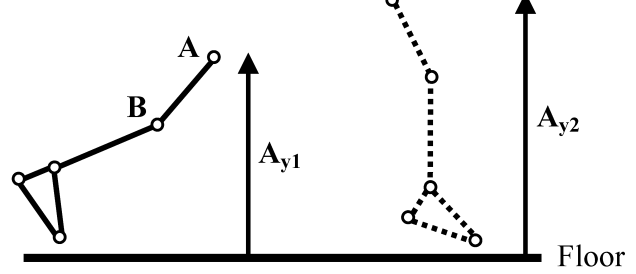

図 4 大転子の変動量の計測位置

Fig. 4. Measurement of moving distance of greater trochanter

位置は上下，左右方向に変動する。歩行中の上下の身体重 心位置の変動量は，小さく滑らかになることで歩行のエネ ルギー消費が減少するとされる(12)。そこでこの変動量を歩 行能力の計測項目として採用した。

本研究では，身体重心位置の変動量を調べるため，人間 の身体重心中心の近くにあるとされる図 4 中の A の位置, すなわち大転子に計測用マーカを付加しこれを計測点とし た ${ }^{(11)}$ 。計測ではデジタルビデオカメラの撮影画像（連続静 止画）より歩行中の大転子の変動量 $\mathrm{A}_{\delta}$ を 2 歩行周期におけ る最大值，最小值から抽出し，時系列データの垂直軸にお ける最大值を $\mathrm{A}_{\mathrm{y} 2}$, 最小值を $\mathrm{A}_{\mathrm{y} 1}$ として $(2)$ 式より求めた。 大転子の変動量は，各対象者の下肢長で除し，正規化した。 下肢長は，対象者の上前腸骨棘から外果までの距離とする。

$$
\mathrm{B}_{\delta}=\mathrm{B}_{\mathrm{y} 2}-\mathrm{B}_{\mathrm{y} 1}
$$

$$
\mathrm{A}_{\delta}=\mathrm{A}_{\mathrm{y} 2}-\mathrm{A}_{\mathrm{y} 1}
$$

$\langle 2 \cdot 2 \cdot 6\rangle \quad$ 歩行バランス値 $\quad 10 \mathrm{~m}$ 歩行時間は，高齢者 の歩行能力を評価するために多くの研究者が用いている。 しかし， $10 \mathrm{~m}$ 歩行時間の計測值には，下肢筋力だけでなく 視覚，深部感覚などの擾乱が影響するため，ばらつきが大 きい(13)。先行研究では, 歩行周期, 立脚相, 遊脚相, 単脚 支持期，両脚支持期の時間が用いられている ${ }^{(14)}$ 。その中で は，加齢変化により歩行中の片脚支持時間の割合が減少し， 両脚支持時間の割合が延長することが報告されている ${ }^{(15)}$ 。 しかし，Ferrandez らは，若年者の遅い歩行でも両脚支持時 間の増加が確認され，高齢者の両脚支持時間の増加が正常 な歩行であると報告している(16)。そのため，高齢者の両脚 支持時間のみに着目することは，歩行能力の計測項目とし て不十分であると考える。

Imms らは歩行バランスを評価するため，立脚相，遊脚相 の時間に着目し，歩行バランスを定量的に評価している(17)。

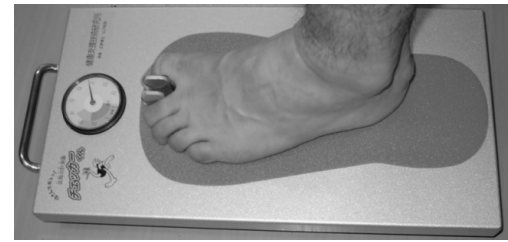

図 5 足指間圧力計測器

Fig. 5. Device for Toe-gap force measurement

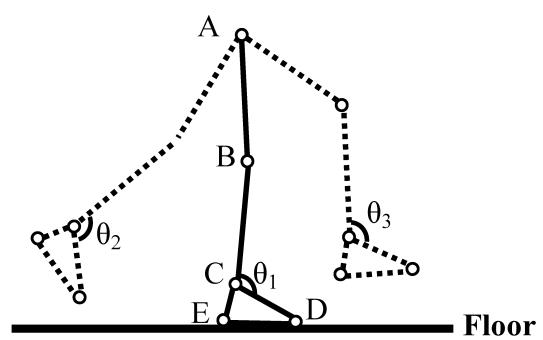

図 6 大転子の変動量の計測位置

Fig. 6. Measurement of rotation range of ankle joint

さらに実験結果では活動性の高い高齢者, 活動性の低い高 齢者, 若年者を比較し活動性の低い高齢者の歩行バランス の值が 2.0 以下, 活動性の高い高齢者と若年者で 2.0 より若 干高いことを報告している。ここでは, 先行研究の歩行バ ランス值を参考に検討を進める。歩行バランス值は( 3 )式よ り求めた。(3)式中の $\mathrm{P}_{\mathrm{t}}$ は立脚相の計測時間[秒]を表し, $\mathrm{S}_{\mathrm{t}}$ は遊脚相の計測時間[秒]を表す。

$$
\text { Walking balance }=\frac{P_{t}}{S_{t}}
$$

\section{$\langle 2 \cdot 3\rangle$ 下肢筋力に関する計測項目}

$\langle 2 \cdot 3 \cdot 1\rangle$ 足指間圧力 足指間圧力の計測では，静的 な状態の下肢筋力を定量的にかつ簡便に評価することがで きる ${ }^{(18)}$ 。図 5 に足指間圧力計測器を示す。足指間圧力計測 は，足母指と第二指間の挟む力を計測するものである。計 測は椅座位で行えるため, 安全かつ簡便に下肢筋力を評価 できる。対象者の姿勢は, 膝関節および足関節を 90 度とし, 踵を上げないように注意した。計測回数は左右 2 回ずつ行 い，2 回のうち大きい方の值を記録した。

\section{$\langle 2 \cdot 4\rangle$ 足首柔軟性に関する計測項目}

$\langle 2 \cdot 4 \cdot 1\rangle$ 足関節動作範囲 Murray らは歩行中の下肢 関節動作範囲の加齢変化を分析し，足関節動作範囲の縮小 などを報告している ${ }^{(19)}$ 。さらに中高年者の歩行中の足関節 動作範囲は, 若年者と比較して約 $50 \%$ 小さくなり足関節可 動性の低下を表す ${ }^{(20)}$ 。すり足歩行は遊脚期で足部をするよ うに歩くことから，足関節動作範囲が制限される。地面か らのつま先高さが最大となるのは, 立脚相初期であり足関 節背屈動作時となる。すなわち足関節動作範囲の制限は, つま先の高さが低下し，踵が持ち上がらないと予測できる。 本研究では歩行中の足関節動作範囲を計測するために, 図 6 中の対象者の B.膝関節外顆, C. 足関節外果, D.第 5 中 足骨粗面, E. 踵にマーカを取り付け(11), デジタルビデオカメ ラより得られたデータから, 歩行中の足関節動作範囲 $\theta_{\sigma}$ を 
求めた。図 6 の $\theta_{1}$ を足関節動作範囲の基準とし， $\theta_{2}$ を足関 節伸展角度, $\theta_{3}$ を屈曲角度とする。足関節動作範囲 $\theta_{\sigma}$ は, (4)式より求めた。

$$
\theta_{\delta}=\left|\theta_{2}-\theta_{1}\right|+\left|\theta_{1}-\theta_{3}\right|
$$

\section{$\langle 2 \cdot 5\rangle$ 実験方法}

$\langle 2 \cdot 5 \cdot 1\rangle$ 対 象 者 対象者は若年者 16 名（平均年齢 $19.9 \pm 0.6$ 歳), 高齢者 10 名 (平均年齢 $80.6 \pm 6.1$ 歳) である。 全ての対象者は自立歩行が可能で心疾患, 脳血管疾患等の 既往歴がないことを確認した。対象者には，計測データを 研究で使用するものであることを十分に説明した。さらに 計測前にも口頭による説明を行い，対象者の同意を得た上 で実験を開始した。計測では支障のでない程度に対象者の そばに実験者が付き添い, 転倒などの予期せぬ事故の防止 につとめ安全に行った。

\section{$\langle 2 \cdot 5 \cdot 2\rangle$ 主成分分析による下肢機能評価手法の作成}

本研究では, 高齢者と若年者の下肢機能の多面的な評価 を行う目的で, 下肢機能の定量的な計測項目を選定し, 計 測から得られたデータを主成分分析によって要約し, 得ら れた主成分得点を用いて，作成した下肢機能の評価手法に ついて検討する。

表 1 に下肢機能評価手法の作成に用いた計 8 つの計測項 目の平均值と標準偏差を示した。足指外転距離が制限され ることは筋力の低下につながる原因となる。本研究の足指 外転距離の計測結果は，加齢による筋力の低下から若年群 より高齢群で低い值になったと考える。また, 足指運動機 能は動的バランスとの相関が高いと報告されていることか ら足指外転距離が歩行能力に関係すると考える。表 1 の足 指屈曲角度の計測結果は, 加齢により若年群と比較して高 齢群の平均值が低い值になったと考える。足指屈曲角度の 低下は，筋力が正常に発揮されない可能性と足母指の動作 範囲の制限につながる。足母指の異常は立脚相後期の蹴り だしの最終的な力の発揮経路であり，足指屈曲角度が制限 されることで歩行に関する蹴りだしの力が低下すると考え られることから, 歩行能力に関係すると考える。表 1 の最 大一歩幅の計測結果では, 若年群と比較して高齢群の平均 值が低い值となり，下肢の前後方向の関節可動域と下肢の 静的な等力が加齢により低下したと考える。また，歩行速 度の減少は下肢前後方向の関節可動域の減少と関係があ り, 歩行阻害要因である。さらに筋力の低下した高齢者歩 行の際に速度を上げるために歩幅よりも歩数を増加してし まい，結果としてバランスを崩すことがある。そのため歩 行能力に関係すると考える。

表 1 の膝関節の上昇値の計測結果は, 若年群より高齢群 が低い值となった。理由として，加齢による筋力の低下か ら立脚相後期の蹴りだしの力が低下したと考える。そのた め, 歩行能力に関係する項目と考えた。表 1 の大転子の変 動量の計測結果は，高齢群と比較して若年群の平均值が高 い值となった。前脛骨筋は歩行中の踵接地後の急激な底屈 を制御し, 重心の下方速度を緩め, 下腿三頭筋の働きによ
る立脚後期からの底屈により重心を滑らかに上方向に押し 上げるとされる。歩行中の上下の身体重心位置の変動量は, 小さく滑らかになることで歩行のエネルギー消費が減少す るとされる。本研究の高齢群の計測結果は若年群と比較し て, 加齢による前脛骨筋の筋力の低下により, 大転子の変 動量が増加し, 歩行中の消費エネルギーが増加したと推測 する。そのため大転子の変動量は歩行能力に関係すると考 える。表 1 の歩行バランス值について, 先行研究より高齢 者において 2.0 以下, 若年者で 2.0 より若干高い值になると 報告がある。本研究結果も同様の傾向が得られたことから 歩行能力に関係する項目と考える。

表 1 の足指間圧力の計測結果では, 高齢群と若年群の平 均值に有意差が確認されなかった。しかし, 若年群の值は 高齢群の值より高い傾向が確認され, 先行研究より足指間 圧力が下肢筋力と関係があり，下肢筋力を定量的に計測で きると報告されていることから下肢筋力に関係すると考え る。

歩行中の足関節動作範囲は, 加齢により小さくなり足関 節可動性が低下寸ると報告されている。表 1 の足関節動作 範囲の計測結果は, 加齢により若年群と比較して高齢群の 值が低い值になったと考える。足関節動作範囲は足首柔軟 性に関係すると考える。

主成分分析の計算には相関行列を用い，主成分分析の結 果より得られた因子負荷量を用い, 結果を表 2 に示した。 固有值が 1 以上の主成分としては，第三主成分まで得られ，

表 1 計測項目の平均值と標準偏差

Table 1. Average and standard deviation of measurement items

\begin{tabular}{lcc}
\hline \multicolumn{1}{c}{ Measurment items [unit] } & $\begin{array}{c}\text { Aged } \\
\text { Average } \pm \mathrm{SD} \\
\mathrm{n}=10\end{array}$ & $\begin{array}{c}\text { Young } \\
\text { Average } \pm \mathrm{SD} \\
\mathrm{n}=16\end{array}$ \\
\hline Distance of extroversion of the toe [cm] & $1.5 \pm 0.7$ & $2.9 \pm 1.0 * *$ \\
Angle of flexion of the toe [deg] & $28.0 \pm 7.1$ & $46.3 \pm 16.6 * *$ \\
Maximum width of step & $1.1 \pm 0.2$ & $1.5 \pm 0.3 * *$ \\
Knee elevation & $0.12 \pm 0.02$ & $0.39 \pm 0.11 * *$ \\
Moving distance of greater trochanter & $0.14 \pm 0.01$ & $0.09 \pm 0.02 * *$ \\
Waling balance & $1.8 \pm 0.1$ & $2.0 \pm 0.2 * *$ \\
Toe-gap force [N] & $2.5 \pm 1.2$ & $3.5 \pm 1.1$ \\
Rotation range of ankle joint [deg] & $37.2 \pm 8.7$ & $44.9 \pm 8.4 * *$ \\
\hline
\end{tabular}

$* * \mathrm{p}<.01$

表 2 主成分分析の結果

Table 2. Results of principle component analysis

\begin{tabular}{l|c|cc}
\hline Measurement item & $\mathrm{C} 1$ & $\mathrm{C} 2$ & $\mathrm{C} 3$ \\
\hline Distance of extroversion of the toe & -0.39 & 0.13 & 0.33 \\
Angle of flexion of the toe & -0.36 & 0.30 & -0.21 \\
Maximum width of step & -0.37 & 0.24 & -0.33 \\
Knee elevation & -0.40 & -0.20 & -0.23 \\
Moving distance of greater trochanter & 0.43 & 0.28 & 0.31 \\
Waling balance & -0.35 & -0.30 & 0.13 \\
Toe-gap force & -0.25 & 0.65 & 0.44 \\
Rotation range of ankle joint & -0.23 & -0.45 & 0.62 \\
\hline Percentage contribution [\%] & 47.9 & 13.6 & 12.6 \\
\hline
\end{tabular}


累積寄与率が $74.1 \%$ あった。第一主成分の寄与率は $47.9 \%$ であった。この主成分において採択された計測項目は，足 指外転距離, 足指屈曲角度, 最大一歩幅, 膝関節の上昇值, 大転子の変動量, 歩行バランス值の 6 項目が挙げられた。 第二主成分に関しては寄与率が $13.6 \%$ あ゙り，足指間圧力 が採択された。第三主成分は，寄与率が $12.6 \%$ \%あり，採 択された計測項目が足関節動作範囲であった。

第一主成分は足指外転距離, 足指屈曲角度, 最大一歩幅, 膝関節の上昇值, 大転子の変動量, 歩行バランス值であり, 歩行能力を表す主成分と解釈した。第二主成分は足指間圧 力, 寸なわち，下肢筋力を表す主成分と解釈した。第三主 成分は，足関節動作範囲であり，足首柔軟性を表す主成分 と解釈した。表 $1 ， 2$ の結果をもとに，以下の算出式から歩 行能力, 下肢筋力, 足首柔軟性の主成分得点を求め, 下肢 機能評価手法を作成した。また，パラメータの係数は各主 成分分析でのパラメータの固有ベクトルの值である。

$$
\begin{aligned}
& \text { 歩行能力 }=(-1) \times\{(-0.39) \times \mathrm{A}+(-0.36) \times \mathrm{B} \\
&+(-0.37) \times \mathrm{C}+(-0.40) \times \mathrm{D} \\
&+(0.43) \times \mathrm{E}+(-0.35) \times \mathrm{F}\} \\
& \text { 下肢筋力 }= 0.65 \times \mathrm{G} \\
& \text { 足首柔軟性= } 0.62 \times \mathrm{H} \\
& \mathrm{A}: \text { 足指外転距離, } \mathrm{B}: \text { 足指屈曲角度, } \mathrm{C} \text { : 最大一歩幅, } \\
& \mathrm{D}: \text { 膝関節の上昇值, } \mathrm{E}: \text { 大転子の変動量, } \mathrm{F}: \text { 歩行バランス值, } \\
& \mathrm{G} \text { : 足指間圧力, } \quad \mathrm{H} \text { : 足関節動作範囲 }
\end{aligned}
$$
$\mathrm{A}$ : 足指外転距離, $\mathrm{B}$ : 足指屈曲角度, $\mathrm{C}$ : 最大一歩幅,
$\mathrm{D}$ : 膝関節の上昇値, $\mathrm{E}$ : 大転子の変動量, $\mathrm{F}$ : 歩行バランス值,
$\mathrm{G}$ : 足指間圧力, $\mathrm{H}$ : 足関節動作範囲

\section{3. 高齢者と若年者の主成分得点の変化}

作成した下肢機能評価手法に基づいて，本研究の対象者 の歩行能力, 下肢筋力, 足首柔軟性を評価した。歩行能力 の平均值と標準偏差は, 高齢者が $11.7 \pm 2.6$ 点, 若年者が 19.2 \pm 6.1 点であった。下肢筋力は高齢者が $1.7 \pm 0.8$ 点, 若年者 が $2.3 \pm 0.7$ 点であった。足首柔軟性は高齢者が $23.0 \pm 5.4$ 点, 若年者が $27.8 \pm 5.2$ 点であった。各主成分得点も高齢者の平 均值より低い值を示したのは若年者に少なく, ほとんどが 高齢者であった。

\section{4. 考察}

本論文では，高齢者や若年者の下肢機能を多面的に評価 することができる下肢機能評価手法を開発するため，下肢 筋力や歩行能力などの 8 つの計測項目を実際に計測し, 得 られたデータから主成分分析を用いて高齢者と若年者にお ける下肢機能評価手法を作成し検討を行った。

計測結果より, 表 1 からは足指外転距離, 足指屈曲角度, 最大一歩幅, 膝関節の上昇值, 大転子の変動量, 歩行バラ ンス值, 足関節動作範囲の計測結果において, 高齢者で若 年者と比べて有意差が認められた。一方，足指間圧力の計 測結果では高齢者と若年者を比べて有意差が認められなか つた。8つの計測項目の主成分分析によって歩行能力, 下肢 筋力, 足首柔軟性の 3 つのパラメータに要約した。さらに 主成分分析の結果をもとに, 歩行能力, 下肢筋力, 足首柔 軟性の下肢機能評価手法を作成した。
作成した下肢機能評価手法に基づいて, 本論文の対象者 の歩行能力を評価した結果より，歩行能力の主成分得点か らは高齢者と若年者を比べると若年者で高齢者に比べて 1.6 倍大きい結果が得られた.

人間の前足部，すなわち足指外転距離や足指屈曲角度は 身体を前方に押し出寸推進力として機能する部分である。 さらに足母指や第 2 指の機能は, 歩行に及ぼす影響が高く 歩行の速度上昇において推進力の確保およびバランス保持 に影響があるとされる ${ }^{(21)}$ 。膝関節の上昇值は, 地面を䟣る ことによる身体を前方に推進させる機能に関係すると考え る。歩行バランス值と大転子の変動量では, 歩行中のバラ ンス機能に関係すると考えられる。すなわち加齢によって 歩行中のバランス保持, 地面を蹴ることによる身体を前方 に推進させる機能が低下したと考えられる。したがって, 歩行能力の主成分得点の結果に表されるように, 若年者で 高齢者に比べ有意に大きい結果が得られたと考える。

下肢筋力を評価した結果より，下肢筋力の主成分得点の 平均值において若年者で高齢者に比べ，高い傾向にあるが 有意差は認められなかった。足指間圧力は下肢筋力と相関 があり ${ }^{(18)}$, 下肢筋力を足指間圧力で計測するという方法は 適していると考えられる。しかし，本論文における高齢者 は, 一日の外出頻度が高いことをアンケート調査より確認 しており，比較的元気な高齢者であると考える。そのため， 下肢筋力の主成分得点について有意差が確認されなかった と考える。

足首柔軟性を評価した結果より，足首柔軟性の主成分得 点の平均值において若年者で高齢者に比べ 1.2 倍大きく有 意差も確認された。すり足歩行は遊脚期で足部をするよう に歩くことから，足関節動作範囲が制限される。本論文の 高齢者は, 要因の 1 つとして加齢によりつま先による立脚 相後期における䟣り出しの力の低下から足関節動作範囲が 縮小したと考える。

本研究の若年群の主成分得点の偏差が大きい理由とし て, 日常生活の歩行距離などが影響したと考える。しかし, 全ての対象者は特別な運動を行っていないことを確認して おり, 実験条件については, 特別な運動を行っている若年 者を対象とするよりも, 安定していると考える。今後は日 常生活の歩行距離などを調查し, グループ分けをすること で安定した計測結果が得られると考える。

\section{5. 結 論}

本論文では，これまでに提案した評価手法に対して，身 体機能が高いと考えられる若年者を加え, 幅広い対象者が 利用できる下肢機能の評価手法を開発した。その結果, 以 下に示すことが明らかになった。

(1) 主成分分析に用いた 8 つ計測項目のデータは, 高 齢者と比較して, 若年者のデータが大きいことが示 唆された。

(2) 主成分分析の結果では, 下肢機能の定量的な計測項 目として選定した 8 つの計測項目を主成分分析に 


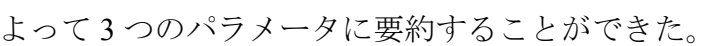

（3）各主成分得点は，高齢者と比較して，若年者の各主 成分得点が高い傾向が確認され，本論文の対象者の 下肢機能の評価手法として使用できることがわか つた。

以上のことから，本研究で作成した下肢機能評価手法を 利用することで高齢者や若年者の下肢機能を評価すること が有効であることを示していると考えられる。

しかし，本実験において歩行の耐久性を評価する項目を 設けなかった。より定量的な歩行能力の評価手法を作成す るためには，歩行の耐久性を評価する項目を検討すること が今後の課題である。

\section{謝 辞}

本研究にご協力いただいた東京都昭島市の施設職員，保 健師, 高齢者の皆様に深く感謝申し上げる。本研究の一部 は，東京電機大学総合研究所 Q09S-04 として行った。

(平成 21 年 6 月 9 日受付, 平成 21 年 10 月 2 日再受付)

\section{文献}

（1）厚生労衔省 : 国民生活基礎調查 (2004)

(2) A. Province, E. C. Hadley, M. C. Hornbrook, L. A. Lipsitz, J. P. Miller, C. D. Mulrow, M. G. Ory, R. W. Sattin, M. E. Tinetti, and S. L. Wolf : "The effects of exercise on falls in elderly patients. a preplanned meta-analysis of the FICSIT trials", JAMA, Vol.273, pp.1341-1347 (1995)

（3）木村みさか・奥野 直・岡山寧子・田中靖人：「高齢者の立位姿勢保 持能に関する一考察」, 体育科学, Vol.26, pp.103-114 (1998)

（4）島田裕之・内山 靖・加倉井周一: 「高齢者の日常生活内容と身体機 能に関する研究」, 日本老年医学会誌, Vol.39, No.2, pp.197-203 (2002)

（5）山下和彦・野本洋平・梅沢 淳 - 宮川晴妃 - 川澄正史 - 小山裕徳 斎藤正男：「高齢者の足部・足爪異常による転倒への影響」, 電学論 C, Vol.124, No.10, pp.2057-2063 (2004)

（6）山下和彦 - 野本洋平・梅沢 淳 - 高野千尋 - 太田裕治・伊野秀一 伊福部達・小山裕徳・川澄正史：「SDA 法を用いた高齢者の姿勢制 御能の評価」, 日本生体医工学会, Vol.45, No.1, pp.121-128 (2007)

（7）野本洋平・川澄正史:「高齢者の足爪の機能改善と歩行能力評価指標 の関係」, ライフサポート学会誌, Vol.19, No.4, pp.19-26 (2007)

（8）野本洋平・山下和彦・宮川晴妃・小山裕徳・川澄正史 :「主成分分析 を用いた高齢者の下肢機能の評価手法の開発」, ヒューマンインタフ ェース学会誌, Vol.9, No.2, pp.109-116 (2007)

（9）山下敏彦・片平弦一郎・倉 秀治・石井清一・横沢 均・太田 勲 成田宽志・石塚明温：「ストレッチングの効果に対する電気生理学的 解析」, 臨床スポーツ医学, Vol.4, pp.47-49 (1987)

（10） 木藤伸宏 - 井原秀俊 - 三輪 恵 ・神谷秀樹 - 島沢真一 ・馬場八千代 田口直彦: 「高齢者の転倒予防としての足指トレーニングの効果」, 理学療法学, Vol.28, No.7, pp.313-319 (2001)

(11) I. A. Kapandji（荻島秀男監訳）：カパンディ関節の生理学 II 下肢, p.242, 医歯薬出版 (1992)

（12）山本澄子：下肢装具のバイオメカニクス一片麻痺歩行と装具の基礎 力学一, 医歯薬出版 (1996)

（13）木村みさか・田中靖人・岡山寧子：「歩行テストからみた高齢者の体 力」, Japanese Journal of Sports Sciences, Vol.14, No.4, pp.435-444 (1995)

(14) 土屋和夫（臨床歩行分析摡談会編）：臨床歩行分析入門, pp.11-23, 医歯薬出版 (1999)

(15) M. Kaneko, Y. Morimoto, M. Kimura, K. Fuchimoto, and T. Fuchimoto Biomechanical analysis of walking and fitness testing in elderly women, In. M. Kaneko(ED.) : Fitness for the aged, disabled, and industrial worker", Human Kinetics Publishers, pp.84-89 (1990)

(16) A. M. Ferradez, J. Pailhous, and M. Durup : "Slowness in elderly gait", Experimental Aging Research, Vol.16, No.2, pp.79-89 (1990)

(17) F. J. Imms and O. G. Edholm : "The assessment of gait and mobility in the elderly", Conference on the Ageing Brain, Vol.8, No.4, pp.261-267 (1978)

(18) 山下和彦・斎藤正男 : 「高齢者の転倒防止能力の足指間圧力計測によ る推定」, 計測自動制御学会, Vol.38, No.11, pp.952-957 (2002)

(19) M. P. Murray, R. C. Kory, and B. H. Clarkson : "Walking patterns in healthy old men", J Gerontology, Vol.24, pp.169-178 (1969)

(20) 益田 允 - 江橋 博: 「中高年齢者の歩行姿勢」, 体力研究, No.21, pp.28-36 (1971)

（21）岩間博哉・竹村 裕 - 上田 淳 - 松本吉央 - 小笠原司：「足指免荷時 足指圧力計測に基づく歩行運動に及ぼす足指機能解明」, 日本機械学 論 C, Vol.70, No.689, pp.213-220 (2004)

野 本 洋 平

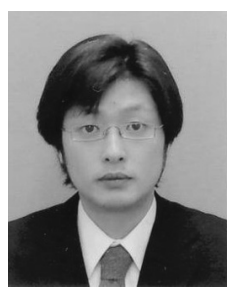

（非会員） 1979 年 5 月 22 日生。 2002 年 3 月東 京電機大学工学部情報通信工学科卒業。2007 年 3 月同大学大学院先端科学技術研究科情報通 信メディア工学専攻博士課程修了。工学博士。 同年財団法人豊田理化学研究所奨励研究員, 2008 年県立新潟女子短期大学生活科学科生活 科学専攻講師, 現在新潟県立大学国際地域学部 国際地域学科講師。専門は生活支援工学, 福祉 工学。日本生体医工学会, 日本生活支援工学会, ライフサポート学 会などの会員。

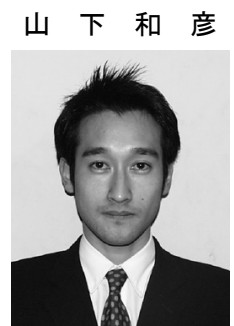

学会などの会員。

（正員） 1972 年 12 月 18 日生。1995 年 3 月東 京電機大学工学部電気通信工学科卒業。2003 年同大学大学院工学研究科情報通信工学専攻 博士課程修了。工学博士。同年豊田理学研究所 奨励研究員, 2005 年東京医療保健大学医療保健 学部医療情報学科講師, 2007 年同准教授。専門 は高齢者工学, 福祉工学, 計測工学。計測自動 制御学会, 日本生活支援工学会, 日本生体医工

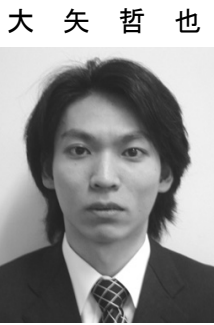

（非会員） 1981 年 3 月 13 日生。 2003 年 3 月東 京電機大学工学部情報通信工学科卒業。2008 年 3 月同大学大学院先端科学技術研究科情報通 信メディア工学専攻博士課程修了。工学博士。 2008 年 4 月より財団法人豊田理化学研究所奨 励研究員。専門は福祉工学。日本生体医工学会, 日本生活支援工学会の会員。

小山裕 徳

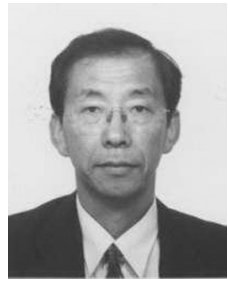

（非会員） 1947 年 9 月 19 日生。1997 年東京大 学大学院工学研究科博士課程修了。工学博士。 同年同大学工学部電気通信工学科講師, 1979 1981 年カリフォルニア大学バークレー校客員 研究員, 1991 年東京電機大学工学部教授, 2007 年同大学未来科学部教授。専門は生体情報工学 で神経インパルス系列の解析や誘発電位の解 析等の研究に従事。日本生体医工学, 電子情報 通信学会, 情報処理学会, 日本人間工学会などの会員。

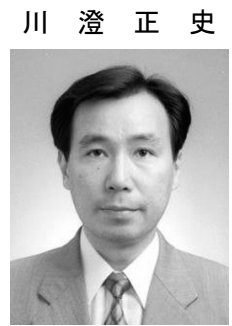

（非会員） 1957 年 11 月 15 日生。1985 年東京 電機大学大学院工学研究科満期退学。工学博士 (東京大学)。1996 1998 年 Yale 大学客員研究 員, 2001 年東京電機大学工学部教授, 2007 年 同大学未来科学部教授。専門は医用生体工学, 生体情報解析, 生活支援工学。ライフサポート 学会, 日本生体医工学会, 日本生活支援工学な どの会員。 